\title{
Prevention and Management Type 2 Diabetes Mellitus on the Risk Groups in Korong Pasar Limau Kepala Hilalang Kecamatan 2x11 Kayu Tanam Kabupaten Padang Pariaman
}

\author{
Elsa Yuniarti ${ }^{1}$, Dezi Handayani ${ }^{1}$, Violita $^{1}$, Syabni Revi Apriyani ${ }^{2}$, Rima Elfita ${ }^{2}$ \\ ${ }^{I}$ Staf Pengajar Jurusan Biologi, Universitas Negeri Padang \\ ${ }^{2}$ Mahasiswa Biologi Universitas Negeri Padang \\ Jl. Prof. Dr. Hamka Air Tawar, Padang, Indonesia \\ dr_elsa@fmipa.unp.ac.id
}

Diterima 7 Maret 2018, Disetujui 8 Maret 2018 Dipublikasikan Maret 2018

\begin{abstract}
West Sumatra with the majority of people are ethnically Minangkabau have a high risk of having type 2 diabetes. Minangkabau ethnic have a special food that is famous for its rich of fat and bersantan but rarely consume vegetables at risk to suffer from DM type 2. The solution that do in answer the above problem is by implementing science and technology activities for society (IbM) Prevention and Management of Type-2 Diabetes Mellitus in the risk group of adults aged 40-85 years who are members of the Posyandu Lansia Mawar Putih I Dusun Sungai Patai dan Posyandu Lansia Mawar Putih II Dusun Batang Paraman di Korong Pasar Limau Kepala Hilalang Kecamatan 2x11 Kayu Tanam Kabupaten Padang Pariaman has never touched the aspect of knowledge, management, prevention and management of type 2 diabetes. In the activities of IbM in the blood glucose during fasting and so found 21 people who fasting blood sugar $\geq 126 \mathrm{mg} / \mathrm{dL}$. From the initial survey the level of knowledge about what diabetes is, generally participants do not understand (82\%) about diabetes. Counseling on Type-2 Diabetes Mellitus given to the Elderly has increased (95\%) understanding, knowledge and skills of the elderly in order to avoid this type 2 diabetes mellitus.
\end{abstract}

Keywords: Diabetes Mellitus type 2, Elderly, Prevention, Management

\section{Pendahuluan}

Prevalensi kemunculan penyakit Diabetes Mellitus pada penduduk dunia tinggi dan semakin meningkat setiap tahunnya termasuk Indonesia maupun Sumatera Barat (Syamsurizal, 2016). Menurut International Diabetes Federation jumlah penderita Diabetes Mellitus pada tahun 2013 sebanyak 382 juta dan diperkirakan akan terus meningkat pada tahun 2035 sebanyak 592 juta (IDF, 2014). Pada tahun 2012, sekitar 1,5 juta kematian secara langsung disebabkan oleh diabetes dan hampir setengah dari semua kematian akibat glukosa darah tinggi terjadi sebelum usia 70 tahun. WHO memproyeksikan bahwa diabetes akan menjadi penyebab utama kematian ke 7 pada tahun 2030 (WHO,2015).

Estimasi jumlah penderita diabetes mellitus di Indonesia menempati posisi keempat terbanyak setelah India, Cina dan Amerika. Estimasi jumlah penderita diabetes melitus di Indonesia tahun 2000 sebesar 4,1\% (8,4 juta dari 205.132.000 orang penduduk
Indonesia). Proyeksi pada tahun 2030 jumlah kasus diabetes melitus di Indonesia akan meningkat mencapai $7,8 \% \quad(21,3$ juta dari 273.219.200 orang) (Perkeni, 2011; Perdomo, 2005).

Berdasarkan penyebabnya diabetes mellitus dikelompokkan menjadi Diabetes mellitus tipe 1 (DM tipe 1), Diabetes mellitus tipe 2 (DM tipe 2), dan Diabetes Gestasional. DM tipe 2 yang paling banyak, ditemui sekitar 90-95\% dari seluruh tipe diabetes yang ada (WHO,2015). Diabetes mellitus (DM) tipe 2 adalah suatu kondisi heterogen yang menggambarkan adanya hiperglikemia berkaitan dengan defisiensi insulin relative (Porth et al., 2009).

Diabetes melitus tipe 2 merupakan salah satu penyakit yang sering dijumpai pada usia lanjut. Hampir $50 \%$ pasien diabetes tipe 2 berusia 65 tahun ke atas. Pada saat ini, jumlah usia lanjut (lansia, berumur $>65$ tahun) di dunia diperkirakan mencapai 450 juta orang (7\% dari 
seluruh penduduk dunia), dan nilai ini diperkirakan akan terus meningkat (Burduli M, 2009) Studi epidemiologi menunjukkan bahwa prevalensi Diabetes Melitus maupun Gangguan Toleransi Glukosa (GTG) meningkat seiring dengan pertambahan usia, menetap sebelum akhirnya menurun. Dari data WHO didapatkan bahwa setelah mencapai usia 30 tahun, kadar glukosa darah akan naik 1-2 mg\%/tahun pada saat puasa dan akan naik sebesar 5,6-13 $\mathrm{mg} \% /$ tahun pada 2 jam setelah makan (Kane et al., 2009). Seiring dengan pertambahan usia, lansia mengalami kemunduran fisik dan mental yang menimbulkan banyak konsekuensi. Selain itu, kaum lansia juga mengalami masalah khusus yang memerlukan perhatian antara lain lebih rentan terhadap komplikasi makrovaskular maupun mikrovaskular dari DM tipe 2 dan adanya sindrom geriatrik (Rochmah W,2007)

DM tipe 2 pada lansia umumnya bersifat asimptomatik, kalaupun ada gejala, seringkali berupa gejala tidak khas seperti kelemahan, letargi, perubahan tingkah laku, menurunnya status kognitif atau kemampuan fungsional (antara lain delirium, demensia, depresi, agitasi, mudah jatuh, dan inkontinensia urin). Inilah yang menyebabkan diagnosis DM tipe 2 pada lansia seringkali agak terlambat (Sclatter A, 2003).

Pada lansia komplikasi DM tipe 2 akan lebih cepat muncul dibandingkan dengan kelompok usia lainnya. Hal ini disebabkan karena pada lansia sendiri sudah terjadi penurunan fungsi sistem organ tubuh yang menjadikan risiko terjadinya komplikasi DM tipe 2 pada lansia menjadi lebih besar. Misalnya penyakit katarak, penyakit ini biasa terlihat pada orang usia lanjut akibat adanya pengerasan lensa yang tak terhindarkan. Namun, pada penderita DM tipe 2 penyakit ini bisa muncul sekitar 10 tahun lebih awal daripada non-DM (Kurniawan I, 2010).

Proses menua menghasilkan perubahan fisiologis yang menyebabkan disfungsi organ dan kegagalan suatu organ atau sistem tubuh tertentu. Meningkatnya populasi lansia dan juga terjadinya perubahan gaya hidup akibat pengaruh globalisasi dapat mengakibatkan timbulnya transisi epidemiologi dimana terjadi pergeseran pola penyakit menular yang diganti oleh penyakit degeneratif. Salah satu penyakit degeneratif yang menjadi masalah penting pada lansia adalah DM tipe 2 (Kane et al., 2009). Jika dilihat sebaran penduduk lansia provinsi Sumatera Barat, persentase penduduk lansia 8.09\% dan sebagian besar bertempat tinggal di desa (BPS, 2012). Karena faktor budaya, banyak orang minang dari rantau jika telah memasuki usia senja ingin mengisi waktu mereka di kampung halaman sampai ajal menjemput.

Prevalensi diabetes melitus di Sumatera Barat 5,2\% (Manaf, 2007). Sumatera Barat dengan mayoritas masyarakatnya beretnis Minangkabau beresiko tinggi menderita DM tipe 2. Etnis Minangkabau memiliki makanan khas yang terkenal kaya lemak dan bersantan tetapi jarang mengkonsumsi sayuran (Liputo et al, 2001). Dilaporkan juga bahwa masyarakat Minangkabau mempunyai kadar kolesterol total lebih tinggi di bandingkan etnis Sunda, Jawa dan Bugis. Asupan asam lemak jenuh populasi Minangkabau sudah 23\% melebihi batas anjuran yang diberikan oleh National colesterol education program yaitu $<10 \%$ dari energi total. Resiko ini diperparah dengan perubahan pola hidup dari pola hidup tradisional yang banyak melakukan aktivitas fisik ke gaya hidup modern yang serba praktis tidak banyak melakukan aktivitas fisik. Sulastri dkk, 2005) dan (Syamsurizal, 2017).

Mengingat besarnya bahaya, luasnya dampak dan risiko diabetes melitus tipe 2 pada lansia seperti yang telah diuraikan maka pencegahannya sangat diperlukan. Salah satu bentuk kelompok masyarakat yang strategis dapat diberdayakan untuk pencegahan diabetes mellitus tipe 2 adalah Posyandu Lansia dimaksudkan untuk meningkatkan pengetahuan dan keterampilan para lansia dalam pencegahan penyakit dan komplikasi dari penyakit Diabetes 
Mellitus tipe 2 pada usia lanjut. Dari data yang didapat di lapangan, Posyandu Lansia Mawar Putih I Dusun Sungai Patai dan Posyandu Lansia Mawar Putih II Dusun Batang Paraman di Korong Pasar Limau Kepala Hilalang Kecamatan 2x11 Kayu Tanam Kabupaten Padang Pariaman belum pernah menyentuh aspek pengetahuan, pengelolaan, pencegahan maupun manajemen diabetes mellitus tipe 2 .

Oleh sebab itu, penulis tertarik untuk melakukan kegiatan Iptek bagi Masyarakat (IbM) tentang Pencegahan dan Manajemen Diabetes Mellitus Tipe-2 pada kelompok beresiko di Korong Pasar Limau Kepala Hilalang Kecamatan 2x11 Kayu Tanam Kabupaten Padang Pariaman.

\section{Solusi dan Teknologi}

1. Sosialisasi dan peninjauan ke lokasi tempat kegiatan pengabdian IbM oleh tim pengabdian dengan melaporkan kepada wali nagari Kepala Hilalang Kecamatan 2x11 Kayu Tanam Kabupaten Padang Pariaman dan kader Posyandu Lansia. Kegiatan ini diadakan pada 2 tempat yakni di Posyandu Lansia Mawar Putih I Dusun Sungai Patai dan Posyandu Lansia Mawar Putih II Dusun Batang Paraman di Korong Pasar Limau Kepala Hilalang Kecamatan 2x11 Kayu Tanam Kabupaten Padang Pariaman.

2. Membuat Leaflet dengan judul Diabetes Mellitus Tipe-2.

Langkah utama yang akan dilakukan adalah:

a. Studi literatur mencari bahan terkini sesuai dengan topik yang direncanakan. Leaflet ini memuat beberapa informasi dengan kalimat yang mudah di pahami oleh para Lansia antara lain: penjelasan umum DM Tipe 2, Faktor resiko DM Tipe 2, Gelaja DM Tipe 2, Diagnosa DM Tipe 2, Komplikasi DM Tipe 2, Pencegahan DM Tipe 2 Manajemen pada penderita DM Tipe 2 termasuk pola asupan gizi dalam pencegahan DM Tipe 2 maupun pola asupan gizi penderita DM Tipe 2 pada Lansia

b. Menulis dan merancang tampilan draft Leaflet

c. Draft Leaflet direview oleh sejawat dan pakar baik dalam materi dan sajian tampilan leaflet.

d. Memperbaiki Leaflet yang telah di koreksi selanjutnya memperbanyak Leaflet di percetakan sebanyak 100 eksemplar.

3. Menyusun materi penyuluhan yang akan disampaikan pada kegiatan Iptek bagi Masyarakat (IbM) tentang Pencegahan dan Manajemen Diabetes Mellitus Tipe-2 pada Kelompok beresiko yakni di Dusun Sungai Patai dan Dusun Batang Paraman di Korong Pasar Limau Kepala Hilalang Kecamatan 2x11 Kayu Tanam Kabupaten Padang Pariaman.

4. Pemeriksaan gula darah sewaktu dan gula darah puasa bagi masyarakat yang berumur 40 sampai 85 tahun di Dusun Sungai Patai dan Dusun Batang Paraman. Bagi lansia yang terindikasi menderita DM tipe 2 di data dan selanjutnya tim akan bekerjasama dengan Puskesmas Sicincin dalam pengobatannya.

5. Membuat rancangan evaluasi dari pelaksanaan kegiatan Iptek bagi Masyarakat (IbM) yang berupa pre test dan post test tentang pengetahuan para lansia tentang penyakit DM Tipe 2 sehingga dapat diketahui apakah kegiatan IbM yang dilaksanakan dapat meningkatkan pengetahuan dan kesadaran Lansia tentang DM Tipe 2 sehingga selalu menjaga kesehatannya. Diakhir kegiatan IbM juga di minta tanggapan tertulis tentang kesan dan pesan terhadap pelaksaan IbM ini.

\section{Hasil dan Diskusi}

Kegiatan Iptek bagi Masyarakat (IbM) Pencegahan dan Manajemen Diabetes Mellitus 
Tipe-2 pada Kelompok beresiko di Korong Pasar Limau Kepala Hilalang Kecamatan 2x11 Kayu Tanam Kabupaten Padang Pariaman telah dilaksanakan di dua lokasi yakni Dusun Sungai Patai dan Dusun Batang Paraman sejak bulan Juli sampai bulan September 2017. Peserta kegiatan IbM adalah orang dewasa dengan umur dari 40 tahun sampai 85 tahun.

Kegiatan penyuluhan dan pemeriksaan gula darah sewaktu di Posyandu Lansia Mawar Putih I Dusun Sungai Patai dan Posyandu Lansia Mawar Putih II Dusun Batang Paraman di Korong Pasar Limau Kepala Hilalang Kecamatan 2x11 Kayu Tanam Kabupaten Padang Pariaman. telah di laksankan pada tanggal 19 Agustus 2017. Distribusi umur dan jenis kelamin peserta kegiatan Iptek bagi Masyarakat (IbM) Pencegahan dan Manajemen Diabetes Mellitus Tipe-2 pada Kelompok beresiko di Korong Pasar Limau Kepala Hilalang Kecamatan 2x11 Kayu Tanam Kabupaten Padang Pariaman dapat dilihat pada gambar 1 dan 2.

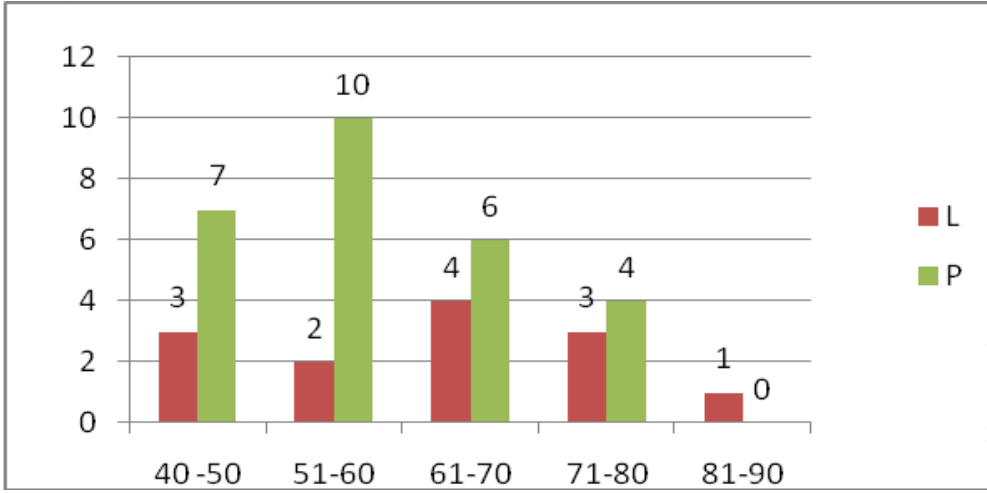

Gambar 1. Distribusi umur dan jenis kelamin di Dusun Sungai Patai

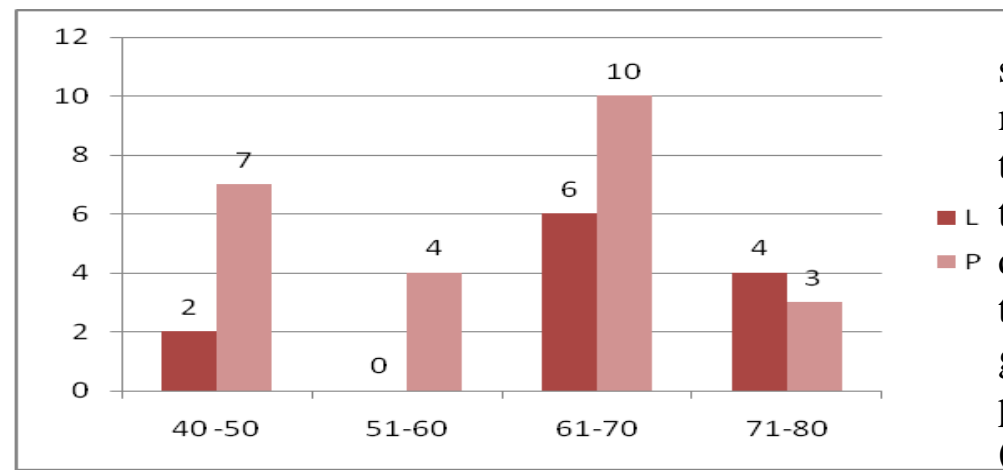

Gambar 2. Distribusi umur dan jenis kelamin di Dusun Batang Paraman

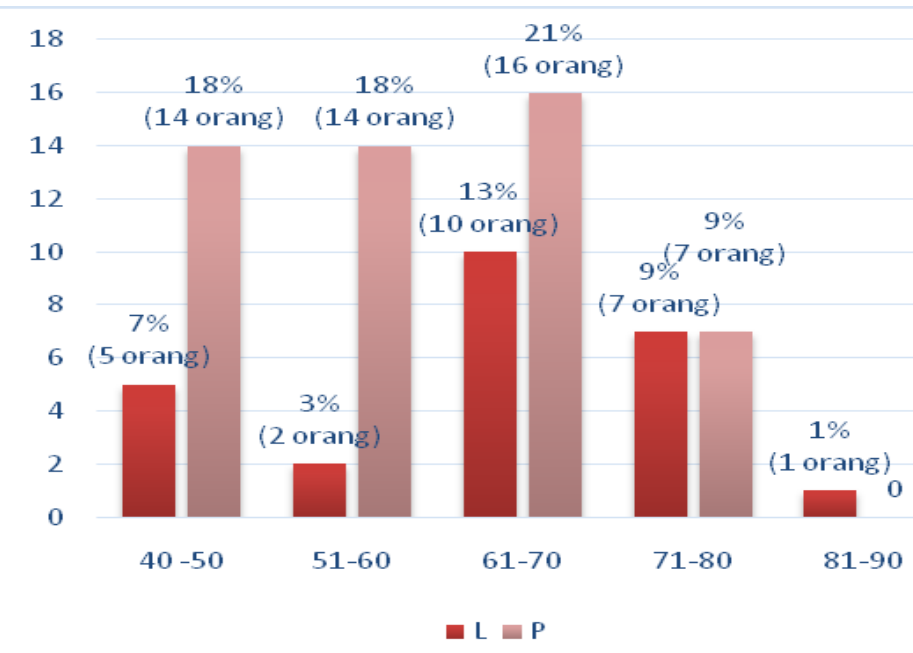

Gambar 3. Distribusi umur dan jenis kelamin peserta kegiatan Iptek bagi Masyarakat (IbM) Pencegahan dan Manajemen Diabetes Mellitus Tipe-2 pada Kelompok beresiko di Korong Pasar Limau Kepala Hilalang Kecamatan 2x11 Kayu Tanam Kabupaten Padang Pariaman

\section{Peserta kegiatan Iptek bagi Masyarakat} (IbM) Pencegahan dan Manajemen Diabetes Mellitus Tipe-2 pada Kelompok beresiko di L Korong Pasar Limau Kepala Hilalang Kecamatan 2x11 Kayu Tanam Kabupaten Padang Pariaman di Dusun Sungai Patai berjumlah 40 orang (laki laki 13 dan perempuan 27) dan Dusun Batang Paraman berjumlah 36 orang (laki laki 24 dan perempuan 12). Total peserta kegiatan IbM sebanyak 76 orang dengan proporsi 37 laki laki dan 39 perempuan dilihat pada gambar 3 .

Sebelum kegiatan IbM dilakukan semua peserta di bantu oleh 5 orang mahasiswa untuk mengisi angket pengetahuan tentang diabetes mellitus. Dari survei awal tingkat pengetahuan tentang apa itu penyakit diabetes, pada umumnya peserta tidak paham tentang penyakit diabetes dapat dilihat pada gambar 3 dan 4 . Tingkat pengetahuan awal peserta dari Dusun Sungai Patai didapatkan 4 (10\%) orang paham dan $36(90 \%)$ orang yang 
tidak paham sedangkan tingkat pengetahuan awal peserta dari Dusun Batang Paraman didapatkan $10(28 \%)$ orang paham dan 26 (72\%) orang yang tidak paham. Kesimpulan dari survey awal tingkat pengetahuan peserta tentang diabetes sebanyak $52(81 \%)$ orang peserta yang tidak paham dan hanya 14 (19\%) orang peserta yang paham.

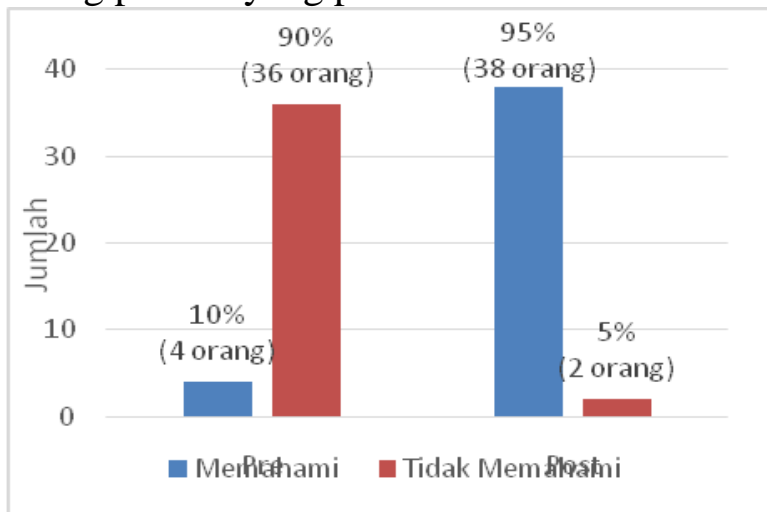

Gambar 4. Distribusi Tingkat Pengetahuan tentang diabetes di Dusun Sungai Patai

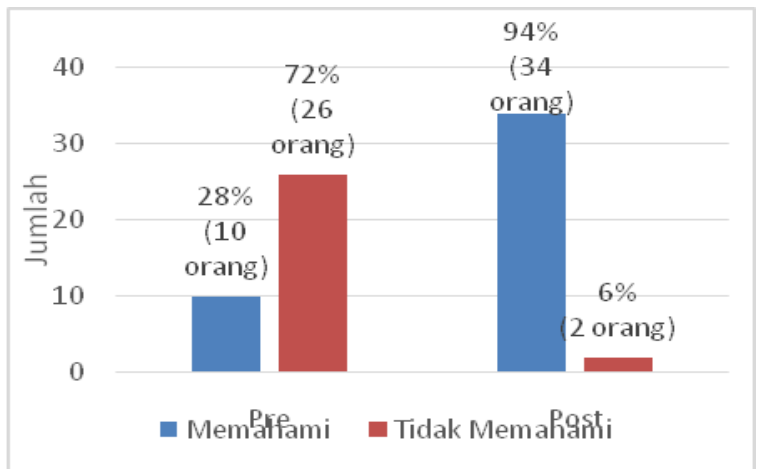

Gambar 5. Distribusi Tingkat Pengetahuan tentang diabetes di Dusun Batang Paraman

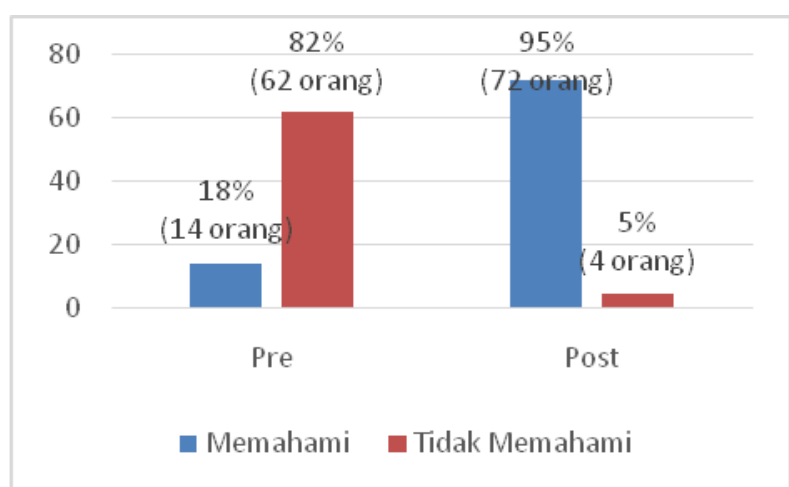

Gambar 6. Distribusi Tingkat Pengetahuan tentang diabetes peserta kegiatan Iptek bagi
Masyarakat (IbM) Pencegahan dan Manajemen Diabetes Mellitus Tipe-2 pada Kelompok beresiko di Korong Pasar Limau Kepala Hilalang Kecamatan 2x11 Kayu Tanam Kabupaten Padang Pariaman

Penyuluhan Diabetes Mellitus Tipe-2 diberikan pada peserta telah meningkatkan pemahaman, pengetahuan dan ketrampilan para lansia agar terhindar dari DM tipe 2. Hasil angket setelah penyuluhan tentang DM tipe pada lansia di berikan terlihat pada gambar 4 dan 5. Tingkat pengetahuan akhir peserta dari Dusun Sungai Patai didapatkan 38 (95\%) orang paham dan $2(5 \%)$ orang yang tidak paham sedangkan tingkat pengetahuan akhir peserta dari Dusun Batang Paraman didapatkan $34(94 \%)$ orang paham dan $2(6 \%)$ orang yang tidak paham. Kesimpulan dari survey akhir tingkat pengetahuan peserta tentang diabetes sebanyak $4(95 \%)$ orang peserta yang tidak paham dan 72 (95\%) orang peserta yang paham terlihat pada gambar 6 .

Pemeriksaan gula darah sewaktu yang dilaksankan pada 19 Agustus 2017 terscreening 14 orang yang menderita DM tipe 2 dengan kadar gula darah sewaktu yang tinggi (lebih dari 200mg/dL) terlihat pada gambar 7 .

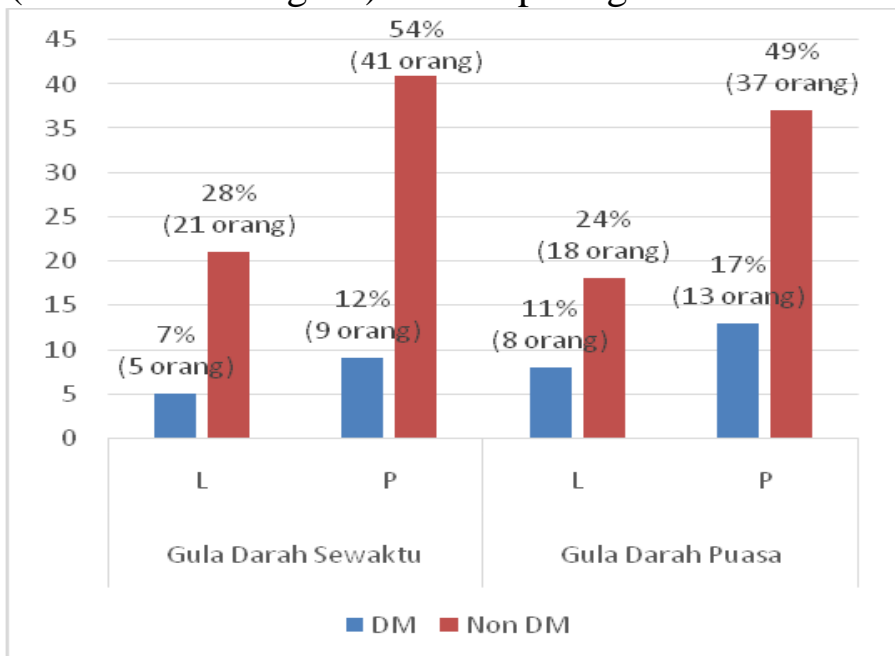

Gambar 7. Distribusi Jenis Kelamin Penderita diabetes peserta kegiatan Iptek bagi Masyarakat (IbM) Pencegahan dan Manajemen Diabetes Mellitus Tipe-2 pada Kelompok beresiko di Korong Pasar Limau Kepala 
Hilalang Kecamatan 2x11 Kayu Tanam Kabupaten Padang Pariaman.

DM tipe 2 pada lansia sering tidak menampakkan gejala yang khas hanya dapat ditegakkan diagnosanya dengan pemerikssan gula darah. Peserta dari Dusun Sungai Patai ditemukan 9 orang (23\%) dari 40 peserta sedangkan dari Dusun Batang Paraman ditemukan 5 orang (14\%) dari 36 peserta yang kadar gula darah sewaktu yang tinggi (lebih dari $200 \mathrm{mg} / \mathrm{dL}$ ) terlihat pada gambar 8 dan 9 .

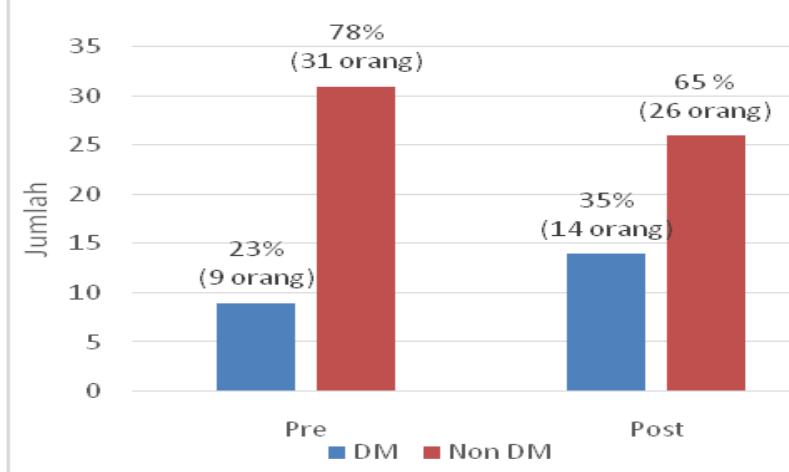

Gambar 8. Distribusi Penderita Diabetes dari peserta Dusun Sungai Patai



Gambar 9. Distribusi Penderita Diabetes dari peserta Dusun Batang Paraman

Kegiatan ini dilanjutkan sebulan kemudian pada bulan 9 September 2017 dengan meminta semua peserta untuk berpuasa selama 10 jam sebelum pemeriksaan gula darah puasa pada peserta. Dengan di pemeriksaan gula darah puasa didapatkan hasil yang pasti untuk menegakkan diagnosa penyakit DM tipe 2 pada lansia. Didapati ada
21 lansia yang masih tinggi kadar gula darah puasanya terlihat pada gambar 7. Peserta dari Dusun Sungai Patai ditemukan 14(35\%) orang dari 40 peserta sedangkan dari Dusun Batang Paraman ditemukan $7(19 \%)$ orang dari 36 peserta yang kadar gula darah puasa yang tinggi (lebih dari $126 \mathrm{mg} / \mathrm{dL}$ ) pada gambar 8 dan 9.

Pada kegiatan ini juga diberian seperangkat alat pemeriksaan gula darah kepada kader Posyandu Lansia Mawar Putih I Dusun Sungai Patai dan Posyandu Lansia Mawar Putih II Dusun Batang Paraman Korong Pasar Limau Kepala Hilalang Kecamatan 2x11 Kayu Tanam Kabupaten Padang Pariaman agar membantu peserta yang terscreening menderita Diabetes Melitus tipe 2 dapat memeriksakan kadar gula darahnya secara rutin sehingga tidak harus pergi ke puskesmas dikarena akses transpotasi dan meluangkan waktu. Disarankan kepada peserta yang terscreening menderita Diabetes Melitus tipe 2 tersebut untuk selalu kontrol gula darah kepada kader dan rutin berobat ke puskesmas untuk mendapatkan obat anti diabetes secara teratur.

Pada akhir kegiatan IbM ini juga di minta seluruh peserta, kader dan wali nagari setempat memberikan pesan dan kesan baik secara tertulis dan lisan terhadap kegiatan IbM yang telah dilaksanakan. Kesan terhadap kegiatan IbM ini seluruhnya mengucapkan banyak terima kasih akan kepedulian instansi Universitas Negeri Padang dan jurusan biologi pada khususnya dengan adanya kegiatan ini peserta yang dapat memeriksakan kadar gula darah dalam pencegahan dan manajemen diabetes mellitus tipe 2 pada peserta yang termasuk kelompok beresiko. Pesan terhadap kegiatan IbM ini agar terus berkelanjutan untuk mendeteksi penyakit metabolik lain seperti penyakit asam urat dan kolesterol.

Dari hasil pengkajian usia pada peserta didapatkan usia 40-50 tahun terdapat 2 orang dan diatas pada usia 50 tahun terdapat 19 orang. Hal ini dipengaruhi karena pada usia 
diatas 40 tahun penyakit ini akan menjadi parakarena insulin yang dibutuhkan di dalam tubuh berkurang karena dengan bertambahnya usia, tubuh mempunyai daya toleransi yang rendah terhadap glukosa. Kondisi ini dapat disebabkan oleh perubahan reseptor glikoprotein yang berinteraksi dengan insulin. Sekresi insulin tidak menurun dengan bertambahnya usia, tetapi yang menurun adalah kepekaan reseptor yang beriteraksi dengan insulin (Hegner \& Caldwell,2003). Pada kelompok umur peserta kegiatan yang paling banyak berusia 50 tahun. Karena pada usia ini kadar darah yang normal akan meningkat secara ringan tapi progresif (bertahap). Terutama pada orang-orang yang tidak aktif bergerak (Kemenkese,2013).

Pada kelompok jenis kelamin penderita diabetes mellitus yang paling banyak yaitu perempuan sebanyak 13 orang dan laki-laki sebanyak 8 orang. Karena pada perempuan mempunyai resiko tinggi ketika hamil (Hasdianah, 2012) dan adanya obesitas karena adanya hormon estrogen yang tidak akan berfungsi dengan baik karena dipengaruhi oleh gaya hidup (Kemenkes, 2013). Usia juga mempengaruhi meningkatnya kadar gula darah. Karena dengan bertambahnya usia, tubuh mempunyai daya toleransi yang rendah terhadap glukosa. Kondisi ini dapat disebabkan oleh perubahan reseptor glikoprotein yang berinteraksi dengan insulin. Sekresi insulin tidak menurun dengan bertambahnya usia, tetapi yang menurun adalah kepekaan reseptor yang beriteraksi dengan insulin (Hegner \& Caldwell,2003). Penderita diabetes mellitus di dalam melaksanakan diet harus memperhatikan jumlah kalori yang dibutuhkan, jadwal makan yang harus diikuti, dan jenis makanan yang harus diperhatikan (Hasdianah, 2012). Ketiganya harus dikendalikan secara bersamaan. Bagi mereka yang berpendidikan tinggi maka akan memperoleh banyak ilmu pengetahuan tentang penyakit maupun cara mengatasinya. Oleh karena itu dalam mengatur kadar gula darah setiap harinya juga berbeda. Sesuai dengan hasil survey melalui angket yang di tanyakan pada peserta, responden makan setiap harinya sebanyak 3 kali. Untuk jumlah makanan yang dikonsumsi tidak dikendalikan. hanya frekuensi. Oleh karena itu, mengkonsumsi makanan secara berlebihan dan tidak diimbangi oleh sekresi insulin dalam jumlah yang memadai dapat menyebabkan kadar gula darah naik (Hegner \& Caldwell,2003).

\section{Kesimpulan}

Kegiatan Iptek bagi Masyarakat (IbM) Pencegahan dan Manajemen Diabetes Mellitus Tipe-2 pada Kelompok beresiko di Korong Pasar Limau Kepala Hilalang Kecamatan 2x11 Kayu Tanam Kabupaten Padang Pariaman telah dapat dijalankan dengan baik dan lancar. Dengan kerjasama tim pengabdian dan peran serta kader Posyandu Lansia Mawar Putih I Dusun Sungai Patai dan Posyandu Lansia Mawar Putih II Dusun Batang Paraman yang aktif dalam menghimpun peserta untuk mengikuti kegiatan IbM ini maka semuanya telah berjalan sesuai yang diharapkan.

Dari kegiatan ini terscreening 21 orang yang menderita DM tipe 2 sebab DM tipe 2 pada lansia sering tidak menampakkan gejala yang khas hanya dapat ditegakkan diagnosanya dengan pemerikssan gula darah. Dari survei awal tingkat pengetahuan tentang apa itu penyakit diabetes, peserta yang tidak paham (82\%) tentang penyakit diabetes. Penyuluhan tentang Diabetes Mellitus Tipe-2 diberikan pada Lansia telah meningkatkan (95\%) pemahaman, pengetahuan dan ketrampilan para lansia agar dapat terhindar dari penyakit DM tipe 2 ini.

\section{Daftar Pustaka}

American Diabetes Association (ADA). 2004. Report of the expert committee on the diagnosis and clasification of diabetes mellitus. Clinical Practice Recommendations, 27, S 5-10. 
Burduli M. The Adequate Control of Type 2 Diabetes Mellitus in an Elderly Age. 2009. Available from: http://www.gestosis.ge/eng/pdf_09/Mary _Burduli.pdf

Hasdianah. 2012. Mengenal Diabetes Mellitus Pada Orang Dewasa dan Anak-Anak dengan Solusi Herbal. Nuha Medika : Yogyakarta.

Hegner, B. R \& Caldwell, E. 2003. Asisten Keperawatan Suatu Pendekatan Proses Keperwatan. Buku Kedokteran EGC : Jakarta.

IDF, 2014, IDF Diabetes Atlas, http://www.idf.org/atlasmap/atlasmap, 23 Januari 2016.

Kane RL, Ouslander JG, Abrass RB, Resnick B. Essentials of Clinical Geriatrics. 6th ed. New York: McGraw Hill; 2009.p.363-70.

Kemenkes. 2013. Diabetes Mellitus Penyebab Kematian Nomor 6 di Dunia :Kemenkes Tawarkan Solusi CERDIK Melalui Posbindu. www.depkes.go.id diperoleh tanggal 23 Oktober 2016.

Lipoeto NI, Agus Z, Oenzil F, Masrul M, Wahlqvist ML. Contemporary Minangkabau food culture in West Sumatera, Indonesia. Asia Pacific Journal of Clinical Nutrition 2001,10:10-16

Manaf A, 2007. Chronic Acute Postprandial Hyperglycemia With Stress Oxidative: The Background of Tissue Damage in Type 2 Diabetes

Perkumpulan Endokrinologi Indonesia. 2011. Konsensus Pengelolaan Diabetes Melitus di Indonesia, PB. PERKENI. Jakarta.

Perdomo RP, 2005. Epidemiology of Diabetes; Prevalence, Complications'and Health
Services Disparities. Para Puerto Rico: Centro de `Diabetes.

Porth, C. M; Hannon, Ruth A; Pooler, Charlotte. 2009. Porth Pathophysiology: Concepts of Altered Health States. United States, Lippincot William-Wilkins.

Porth, C.M. 2010. Essentials of Pathophysiology: Concepts of Altered Health States. United States, Lippincot William-Wilkins.

Sclatter A. Diabetes in the Elderly: The Geriatrician's Perspective. Can J Diab. 2003;27(2):172-5. Available from: http:// www.diabetes.ca/files/ElderlySclaterJune 03.pdf

Sulastri, D., S. Rahayuningsing dan Purwantyastuti. 2005. Pola asupan lemak, serat dan antioksidan serta hubungan dengan profil lipid pada etnik minamgkabau. Majalah Kedokteran Indonesia, Vol 2, pp 55-56.

Syamsurizal, Syamsurizal. (2016). Jumlah Sulur sebagai Penanda Diabetes Mellitus Tipe-2 Etnis Minangkabau. Biospecies, 9(2).

Syamsurizal, Syamsurizal. (2017). Sudut ATD sebagai Penanda Diabetes Mellitus Tipe-2 (DMT2). BioScience, 1(1), 1-8.

Rochmah W. Diabetes Mellitus pada Usia Lanjut. In: Sudoyo AW, Setiyohadi B, Alwi I, Simadibrata M, Setiati S, editors. Buku Ajar Ilmu Penyakit Dalam. 4th ed. Jakarta: Pusat Penerbitan IPD FKUI; 2007.p.1915-18.

WHO, 2015, Diabetes Fact Sheet,http://www. who.int/mediacentre/factsheets/fs312/en/, 22 Januari 2016. 